\title{
Studying the effects of nucleating agents on texture modification of puffed corn-fish snack
}

\begin{abstract}
To improve textural attributes of puffed corn-fish snack, the effects of $1 \%, 1.5 \%$, and $2 \%$ of calcium carbonate, magnesium silicate (talc), sodium bicarbonate as well as 5\% and $10 \%$ of wheat bran (as the nucleating materials) on textural attributes were studied. Sensory evaluation, bulk density, expansion ratio, maximum force, and count peaks were measured using the Kramer test. The results showed that all of the additives except bran significantly enhanced the texture. Among them, talc at $0.5 \%$ was the best to enhance the density and expansion ratio. Effects of using $0.5 \%$ talc on puffed corn-fish snack microstructure were studied using scanning electron microscopy. The average cell diameter of $109 \pm 48 \mu \mathrm{m}$ and cell numbers per square centimeter of 67.4 for talc-treated products were obtained, while for nontalc-treated extrudates, average cell diameter of $798 \pm 361 \mu \mathrm{m}$ and cell numbers per square centimeter of 13.9 were found. Incorporation of $0.5 \% \mathrm{w} / \mathrm{w}$ of magnesium silicate reduced (7-fold) the average cell diameter while increased (4-fold) the cell number.
\end{abstract}

Keyword: Fish; Magnesium sicrostructure; Snack; Scanning electron microscopy 